\title{
Balkanologie
}

Balkanologie Revue d'études pluridisciplinaires

Vol. VIII, $n^{\circ} 1$ | 2004

Volume VIII Numéro 1

\section{The Role of International Community in Conflict Situation. Which Way Forwards?}

The Case of the Kosovo/a Conflict

Le conflit au Kosovo et la diplomatie internationale

\section{Enika Abazi}

\section{OpenEdition}

\section{Journals}

Édition électronique

URL : http://journals.openedition.org/balkanologie/511

DOI : 10.4000/balkanologie.511

ISSN : 1965-0582

\section{Éditeur}

Association française d'études sur les Balkans (Afebalk)

Édition imprimée

Date de publication : 1 juin 2004

ISSN : 1279-7952

\section{Référence électronique}

Enika Abazi, «The Role of International Community in Conflict Situation. Which Way Forwards?», Balkanologie [En ligne], Vol. VIII, $n^{\circ} 1$ | 2004, mis en ligne le 21 janvier 2010, consulté le 17 décembre 2020. URL : http://journals.openedition.org/balkanologie/511 ; DOI : https://doi.org/10.4000/ balkanologie. 511 


\section{THE ROLE OF INTERNATIONAL COMMUNITY IN CONFLICT SITUATION. WHICH WAY FORWARDS ? THE CASE OF THE KOSOVO/A CONFLICT}

Enika Abazi*

The changes and continuities of international community policies towards the Kosovo/a conflict involved a contested reorientation of attitude intimately tied up with the preservation of international peace, regional order and existing institutions. The prerequisites of order shaped at a significant degree the behaviour and the arrangements of international community to the settlement of the case. Accordingly, the attitude and the engagement of international community in the Kosovo/a case can be explained in terms of these prerequisites rather than the intrinsic causes of the conflict. These arrangements offered by international community as solutions to Yugoslav dissolution process did significantly affect the development of the Kosovo/a conflict. These policies failed to produce consensus between the parties in conflict, instead, as the paper would try to demonstrate, they played the role of a catalyst in the initiation of the conflict. Therefore, this paper, by offering a detailed reconstruction of the process by which the international community tried to settle the Kosovo/a case ${ }^{1}$, would seek to demonstrate how the dynamics of the conflict interacted dynamically with international community attitude and policies towards the case. The paper would discuss the attitude and policies of international community toward the Kosovo/a case underlining its attachment to traditional prerequisites of international order instead of inherited causes of conflict.

There are three important events that underline the interference of international community in the case of Kosovo/a before the war happened : the Conference on Yugoslavia that followed up the creation of the Badinter com- 
mittee, the Dayton Agreement and the Rambouillet Talks. These events would be explained in details in three separate sections since they have immediate implications for the situation in Kosovo/a and consequently for the development of the conflict. For the purpose of this paper the analysis would follow the logic of first, discuss the contribution of existing normative framework to models of international community behaviour and their effects in the case of Kosovo/a conflict following with the reaction of the conflicting parties towards offered arrangements. Both moments are assumed to be of importance in providing a larger picture in the understanding of the Kosovo/a conflict outgrowth. The paper would conclude with some critical observations on traditional premises of order and their relevance in the case of intra-State conflicts.

\section{INTERNATIONAL ORDER AND INTRA-STATE CONFLICT}

War is considered to be a separate and present institution of international order, a State-to-State practice that " international society itself feels a need to exploit so as to achieve its own purposes $n^{2}$. There is a dual countenance in this consideration. First, following this logic not every kind of violence could be considered as war. Within the modern State system only war waged by sovereign States (inter-State war) has been recognized as a purposive activity with defined functions in international society ${ }^{3}$. Second, international society limits rather that prohibit the use of force among the States.

International society has sought to limit the right to go to war by forwarding and legitimizing a set of principles : legitimizing States as belligerents ; circumscribing war's worst excesses by agreed frameworks ; limiting the disruption and damage to third parties and " restrict the reasons or causes for which a State can legitimately resort to war "4. Thus, the society of States aims to discipline or control war through « diplomatic procedures, treaties, international laws, wars, and all other institutions that provide for communications and interaction among the States " founded " on the mutual recognition among government leaders that they each represent a specific society within an exclusive jurisdictional domain ${ }^{5}$. In many respects this normative framework is restrictive in understanding changing practices of international relations such as intra-State conflicts. Although, international

\footnotetext{
${ }^{2}$ Bull (Hedley), An Anarchical Society. A Study of Order in World politics, London : Macmillan, 1977, p. 188. ${ }^{3}$ Bull defines war as a mean of " enforcing international law, of preserving the balance of power, and arguably, of promoting changes in the law generally regarded as just " (ibid.).

4 Ibid.

${ }^{5}$ Barkin (J. Samuel), Cronin (Bruce), " The State the Nation : Changing Norms and Rules of Sovereignty in International Relations ", International Organization, 48 (1), Winter 1994, p. 110.
} 
order initial premises were based on the accounts of change and dialectics of development of inter-State relation they seem restrictive facing the practices of intra-State conflicts.

The traditional normative framework seems to be limited in facing the reality of intra-State conflicts where most of the belligerent parties demand for self-determination ${ }^{6}$. The requests of sub-State actors that demand recognition and self-determination, in the same basis as the States, are considered as illegal as long as non-State actors are not recognised as States. The recognition of such a right is a political act more than a legal and moral obligation in Inis Claude's terms ${ }^{7}$; an act that otherwise represents " a good deal of functional accommodation ${ }^{8}$ embedded in the society of States. Accordingly, the accommodation offered to the requests of belligerent parties stands for the political expression of shared consent among States, that pledges the preservation of the present territorial borders in the international system, censors the right of self-determination to belligerent parties and legitimises States' refusal in accepting change in this framework. These attitudes have materialised in a normative framework that holds the consistency of an empirical law, which at the same time prescribes the attitude of international community toward intraState conflicts including the case of Kosovo/a. At the same time it reveals the international community impasse toward these conflicts and the limitations of arrangements prescribed to the case.

Argumentation here above assessed international society difficulty to deal with intra-State conflicts that are considered of disturbance for the sovereignty of the State and international order. These difficulties are manifested in the controversies of international community policies and attitudes of international community towards these conflicts. The paper would follow by providing empirical evidence on international community arrangements on the case of dissolution of Yugoslavia with particular emphasis on the case of Kosovo/a. These arrangements could be considered " normal " decisions under the prerequisites of order and the traditional normative framework, which objective interests is the preservation of State territorial integrity. However, based on the concerns for order international community involvement in the case of Kosovo/a did exercise a problematic influence over the conflicting parties and consequently to the causation of the conflict. In Oberg's terms " the

\footnotetext{
${ }^{6}$ Self-determination is recognised as " the right or aspiration of a group, which considers itself to have a separate and distinct identity, to govern itself and to determine the political and legal status of the territory it occupies " (Evans (Graham), Newnham (Richard), Penguin Dictionary of International Relations, London : Penguin Books, 1998, p. 97).
}

7 Claude (Inis L. Jx.), " Collective Legitimization as a Political Function of the United States ", International Organization, 20 (3), September 1966.

${ }^{8}$ Buzan (Barry), " From International System to International Society : Structural Realism and Regime Theory Meet the English School n, International Organization, 47 (3), Summer 1993, p. 334. 
international community (...) has been an integral party to the conflict, not an impartial mediator $" 9$ and as such it could assume part of the blame for the outgrowth of war. The international community in general and the EU in particular that took the lead on resolving normative problems related with the dissolution of Yugoslavia, did not resolve many problems that later added up to the causes of conflicts in Bosnia, Kosovo/a and Macedonia. The paper would try to provide evidence that the arrangements offered by international community did exuberate State-society tensions (Serbian State-Kosovo Albanians) up to the point that offered arrangements towards the Kosovo/a case needed to be re-considered stepping over the traditional normative framework. International endeavour with effects in the Kosovo/a case could be divided in three periods according to the different effects it exercised on the development of the conflict : 1991-1995, 1995-1998, and 1998-1999. The paper would follow by discussing the empirical evidence of international community arrangements starting from the dissolution of Yugoslavia and their effect on the development of the Kosovo/a conflict.

\section{PEACE CONFERENCE ON YUGOSLAVIA, BADINTER COMMITTEE AND THEIR ROLE IN KOSOVO/A CONFLICT [1991-1995]}

Peace conference on Yugoslavia that was hosted by Lord Carrington in August 1991 established the European Community Monitoring Mission recognised as Badinter Committee embodied with the authority ${ }^{10}$ of negotiating solutions for the dissolution of Yugoslavia. The Conference was considered a compromise that would bring together the Federal Presidency, the Federal Government and the Presidents of the Republics. It provided a framework for actions based on practices that were applied before in the similar cases of decolonization in Africa and elsewhere. The main issues to deal were as Pellet define : " the scope of the self-determination principle as it is applied in particular contexts, with a special focus on de-colonisation; the relationship of this

\footnotetext{
9 Oberg (Jan), "TFF on CNN - $3^{\text {rd }}$ time on Kosovo ", Pressinfo, 27/01/oo (electronic version at: http://www. transnational.org/pressinf/200o/pf84.html).

10 Some authors would challenge the decision-making legitimacy of the Badinter Committee. For more on this topic see Williams (John C.), Legitimacy in International Relations and the Rise and Fall of Yugoslavia, New York : St Martin Press Williams, 1998, pp. 130-131, 138, 140-141; Akhavan (Payam), "SelfDetermination and the Disintegration of Yugoslavia : What Lessons for the International Community? ", in Clark (Donald), Williamson (Robert), eds., Self-Determination. International Perspectives, New York : St. Martin Press, 1996, pp. 227-228, 233-235, 240-242. However the issue of legitimacy would not be discussed in this paper since it goes beyond its purpose.
} 
principle to an other of equally fundamental importance, that of stability of frontiers ; and finally, the general role which an international arbitration body might play in such problems $"^{11}$.

International community in the case of dissolution of Yugoslavia was led in its actions by " imperative norms " and democratic and human values considerations. These actions aimed to " ensure a peaceful accommodation of the conflicting aspirations of the Yugoslav peoples ${ }^{12}$. In his practices international community, was careful to provide an acceptable balance between the sovereignty equality and independence of States on the one hand and the reality of an interdependent world and the international law commitment to human dignity on the other. The two main Documents issued by the Conference : the Statement and the Guidances on Recognition did set the limits of self-determination and the rules of the game on the behalf of the Yugoslav successive States. In Hasani's words " the Yugoslav self-determination ever since has remained unchanged and has followed the basic premises foreseen by those two documents $"^{13}$. The question of self-determination as a safeguard of the human rights (International Convenants on Human Rights, 1966) was guaranteed without questioning the sovereignty of the State. Accordingly, in the case of Kosovo/a, Albanians may demand and obtain the recognition of their nationality but at the same time retain their civil and political rights within the State of Serbia. The rights of Kosovo/a Albanians and other national groups such as Serbs in Krajina (Croatia) and Hungarians in Vojvodina (Serbia) were going to be plead through precise mechanisms, bringing with them guarantees, which have to be negotiated and settled at the international level. Accordingly, the recognition of sovereignty was conditioned by these requirements : " Republics must afford the members of those minorities and ethnic groups, all the human rights and fundamental freedoms recognised in international law, including where appropriate, the right to their nationality $n^{14}$.

In this way, the model offered for Yugoslav self-determination was defined in a way that avoid major discrepancies form the concept of territorial exclusivity while assuring order and stability through the promotion of democracy and human rights values. Democracy, rule of law, respect of human and minority rights was offered to all Yugoslav republics as a precondition for re-

\footnotetext{
${ }^{11}$ Pellet (Alain), " The Opinions of the Badinter Arbitration Committee. A second Breath for the SelfDetermination of Peoples ", European Journal of International Law, 3, 1992, p. 179.

12 " EC Declaration on Yugoslavia (3 September 1991) n, Adopted at the European Peace Conference Extraordinary Ministerial Meeting, The Hague, cited in Trifunovska (Snezana), ed., Yugoslavia Through Documents, The Hague : Martinus Nijhoff Publishers, 1994.
}

${ }^{13}$ Hasani (Enver), Self-Determination, Territorial Integrity and International Stability. The case of Yugoslavia, Bilkent : Bilkent University Library (Ph.D. Dissertation), 2001, p. 205.

14 Opinion 2 of the Arbitration Commission, 1991, as cited in Pellet (Alain), art.cit., p. 184. 
cognition. These values were sanctioned in the constitution of all successive States and this policy represents a continuous general trend of Western policies towards succession cases in general ${ }^{15}$. Here, lied the novelty of Badinter committee : relating basic premises of international order, such as territorial exclusivity right, with the respect and establishment of democratic and human rights values. The challenge behind this combined normative and emancipatory endeavour is the lack of binding authority and commitment to enforcement of human rights and democracy by all means ${ }^{16}$.

The other issue that was considered by the Badinter committee was the settlement of the frontiers. Uti Possidetis Juris (respects for the frontiers existing at the moment of independence) was applied as a principle in border definition, based on the procedures used by the UN in the case of post-colonial settlements. In the case of Yugoslavia, the solution about the frontiers of the new States was "found in the disassociation of the concept of nationality from that of territory $"^{17}$. Accordingly, the borders of the Republics in the framework of the Federation were preserved. This practice based on the preeminence of the principle of territorial integrity associated with the principle of peace and international stability was considered universal and peremptory and as such could not be disregarded in the consideration of the Yugoslav case. The demand of Kosovo/a Albanians for treatment of their case in equal footing with the other Republics of Yugoslav Federation was refused based on this principle.

The Kosovo/a Albanian leadership argued in " Letter by the Government of the Republic of Kosova to the Extraordinary EPC Ministerial Meeting in Brussels, 21 December 1991 " $^{18}$ that Kosovo/a within the framework of the 1974 Constitution enjoyed equal right of representation at Federal level, although, having the status of autonomous region. Therefore, based in this argument it was asked that Kosovo/a needed to be considered as a constitutive unit of the Yugoslav Federation as the other Republics. However, the case was considered not endowed with sovereignty by Badinter Committee as such solutions for

\footnotetext{
15 Kamminaga (Menno T.), "State Succession in Respect of Human Rights Treaties ", European Journal of International Law, 7 (4), 1996 ; Vereshchetin (Vladen S.), "New Constitutions and the Old Problem of the Relationship Between International and National Law ", European Journal of International Law, 7 (1), 1996.

16 Different no-coercive means were used by international community to ensure the enforcement of common decisions on the protection of the human rights such as peacekeeping, sanctions, and international not-recognition, which in the case of Kosovo/a was materialised, with introduction of the "outer wall of sanctions $n$ upon Serbia. More about sanctions and their effects on the conflict would be written latter on this section.
}

${ }_{17}$ Pellet (Alain), art.cit., p. 180.

${ }^{18}$ Academy of Science of the Republic of Albania, ed., The Truth on Kosovo/a, Tirana : Encyclopedia Publishing House, 1993, p. 329. 
Kosovo/a case were not negotiated in the framework of the dissolution of Yugoslavia as for the other Republics.

The case of Kosovo/a was left under the custody of the Republic of Serbia that was going to look at its own interests and security and of its own constituents first and foremost in concordance with international obligations of respects for human rights. In such a case, the right of external self-determination was denied to Kosovo/a. The human rights prerequisite offered as solution in the case of Kosovo/a was the modus vivendi that saved international community from tackling the issue of external self-determination of different nationalities in Yugoslavia. The decision of Badinter Committee was based on a formal ${ }^{19}$ application of the international law, which revealed to be deprived from the reality of relations between Serbs and Albanians.

Well before the forceful dissolution of Yugoslavia started, the relations between Serbs and Kosovo/a Albanians grew soar. Since, 1988, tension further grew in Kosovo/a. A series of incidents and provocation followed up the policies of Milošević for the removal of the status of the autonomy of Kosovo/a and reducing it in a simple administrative entity within the Republic of Serbia ${ }^{20}$. Still, Kosovar Albanian student leaders on 5 January 1998 called for a peaceful and democratic solution to the current tensions in "Serbia's mainly ethnic Albanian province ${ }^{21}$. However, the regime of Milošević continued with its repressive methods in Kosovo/a. The consequences of these continuous conflictual violent prone policies were the escalation of the responses towards arbitrary measures on the side of Kosovo/a Albanians ${ }^{22}$.

On July 1990, Albanian delegates of the Kosovo/a Assembly declared Kosovo/a an " independent and equal entity within the framework of the Yugoslav Federation and as an equal subject with its counterparts in Yugoslavia $n^{23}$. Facing the increasing militarist policies of Serbia in the region, in September 1991, a clandestine referendum was organised and with a yes of

19 Badinter Committee applied in a new context the disposition of the international law that was completed during the formalisation of the de-colonising process.

${ }^{20}$ In March 1989, a demonstration of Albanians took place asking for " Kosovo/a Republic ". Soon after, in the celebrations of Kosovo/a for the $600^{\text {th }}$ anniversary of the battle of Kosovo/a in Kosovo/a Field (Polje), Milošević promised to the Serbs that " nobody would bit you again " (Isakovic (Zlatko), " Diplomacy and the Conflict in Kosovo - Notes on Threats and Fears ", International Studies Association, Washington, February 16-20, 1999, p. 1). Following suit this anniversary, constitutional changes were adopted to allow the changing of the status of the region. In September 1990, the Serbian parliament adopted a new constitution, which definitively abolished the status of autonomy for Kosovo/a.

${ }^{21}$ RFE/RL, " Kosovo Students Urge Peaceful Solutions ", (189 part 2), 08/01/98.

${ }^{22}$ Clark (Howard), Civil Resistance in Kosovo. London : Pluto Press, 2000.

23 " Constitution Declaration of the Assembly of Kosovo, Prishtina, 2 July 1990 ", in Academy of Science of the Republic of Albania, ed., op.cit., p. 329. 
$87,01 \%$ of the voters an independent and sovereign State of Kosovo/a was proclaimed ${ }^{24}$

Badinter committee ignored the self-declared independence of Kosovo/a and the requirements of Kosovo/a Albanian leadership for a Kosovo/a independent and equal entity within the framework of Yugoslavia. Thus, the dispositions of the Guidance or Recognition Document were applied in an arbitrary way without negotiating it with all interested parties in Yugoslavia. The agreement was imposed by one party-international community, as a pre-requisite for the preservation of stability at regional and international level. This decision did just froze the situation from escalation towards conflict at international level while polarized the positions of conflicting parties and radicalised their demands. In the framework of Yugoslavia, some scholars would charge Badinter Committee decisions as the very cause and direct accomplice of the dissolution of Yugoslavia and all the tragedies that followed ${ }^{25}$. By the end of the 1991, the Conference failed to prevent the war being committed exclusively to peacekeeping actions as a substitute for military interventions ${ }^{26}$. Therefore, little was done by international community to stop "Serbs in Bosnia and Croatia from engaging in ethnic cleansing to create Serb ruled enclaves that they hoped to join to Serbia itself $n^{27}$. Drawing parallels between Serb policies in Bosnia, Croatia and Kosovo/a tacitly a message was conveyed to the Serbs, there was not going to be military intervention in Kosovo/ $\mathrm{a}^{28}$.

The limitation of existing normative framework accommodated pre-tailored decisions of international community to the problems embarking from the dissolution of Yugoslavia. The decisions yielded ambiguity since the present normative framework being shaped for the State interrelation framework make it difficult to offer solutions to unseemlier cases. Consequently, the deci-

\footnotetext{
24 Troebst (Stefan), " Conflict in Kosovo : Failure of Prevention ? An Analytical Documentation, 19921998 ", ECMI Working Pape, (1), 1998 ; Silber (Laura), " Defiant Serbian Province Votes on Independence ", Washington Post, 25/05/92 ; Maass (Peter), "Serbians Pressing Ethnic Albanians in Uneasy Kosovo ", Washington Post, $15 / 07 / 91$.
}

${ }^{25}$ Raju (Thomas), "Nations, States and Secession : Lessons from the Former Yugoslavia ", Mediterranean Quarterly, 5 (4), Fall 1994 ; Radan (Peter), " The Badinter Arbitration Commission and the Partition of Yugoslavia ", Nationalities Papers, 25, 1997.

${ }^{26}$ Berdal (Mats R.), " Whither the UN Peacekeeping ? ", Adelphy Paper, (281), 1993 ; Tharoor (Shashi), "United Nations and Peacekeeping in Europe ", Survival, 37, Summer 1995; Rossanet (Bertrand de), Peacemaking and Peacekeeping in Yugoslavia, The Hague : Kluwer Law International, 1996.

27 Thies (Wallace J.), "Compellence Failure or Coercive Success ? The Case of NATO nad Yugoslavia ", Comparative Strategy, 22 (3), July 2003, p. 246.

${ }^{28}$ In 19-29 December 1992 there was a warning to Serb leadership by Bush administration to not widen the war. In the case Serbs would attack Kosovo/a Bush threaten the use of military force (Binder (David), "Bush Warns Serbs Not to Widen the War ", New York Time, 28/12/92 ; Goshko (John M.), " Bush Threatens "Military Force" if Serbs Attack Kosovo Province ", Washington Post, 29/12/92). 
sions of Conference were ambiguous and not conclusive as such they gave free hand to local actors to choose the means to fulfil their expectations and preferred solutions. In most of the cases that designed the picture of Yugoslav dissolution, violence was chosen by the local actors as the mean to achieve their predefined ends. However, from this generalisation should be excluded the case of Kosovo/a and Macedonia that looked in the beginning of dissolution of the Federation to find solution by peaceful means.

As for the case of Kosovo/a, that was not part of the principal deal, the Conference document on Guidance of Recognition conveyed mixed messages to the conflicting parties in Kosovo/a. Belgrade views the case of Kosovo/a as an internal issue of Serbia State that by all means should not be internationalised. The conference did not commit itself to use military force to uphold the war in case the secession did not succeed by compromise. Under these circumstances, Milošević felt safe in pursuing his war goals, considering the Conference a mediatory agency without any biding effect on the parties in conflict.

On the other hand, the solutions that were offered in the Guidance on Recognition document suggested internal self-determination for the Kosovo/a Albanians. This decision in same way challenged the preservation of the status quo in the ground ${ }^{29}$. The decision taken by Milošević for the removal of the autonomy status from Kosovo/a and Vojvodina, made Serbia a centralised republic within the framework of Yugoslav Federation and as such the space for the self-declaration of other nationalities within Serbia was undermined considerably. In a combined way, with the decisions of Badinter Committee the independence of Kosovo/a was denied. However, Serbia as a recognised republic under Badinter Committee decisions was prevented from exercising its full sovereign rights as a centralised republic since two provinces : Kosovo/a and Voyvodina did enjoyed under the same provisions the right of internal self-declaration within the republic of Serbia. The controversy in the Guidance for Recognition document promoted insecurity since none of the parties in question was clear for its status within Serbia that was recognised as constituent part of the Yugoslav Federation.

The moment, the decisions of the Badinter Committee were made clear an organised not-violent " civil resistance $" 3^{\circ}$ of the Kosovo/a Albanians against Serbia started. Positions hardened and the process of continuous exercise of

\footnotetext{
${ }^{29}$ Wiberg (Håkan), "Identifying Conflicts and Solutions ", Romanian Journal of International Affairs, 4 (1), 1998 ; Oberg (Jan), " Conflict Mitigation in Former Yugoslavia-It Could Be Still Possible ", in Nakarada (Radmila), ed., Europe and Disintegration of Yugoslavia, Belgrade : Institute for European Studies, 1998 ; Troebst (Stefan), art.cit.
}

${ }^{30}$ Clark (Howard), op cit. 
violence and oppression accelerated towards the Albanians in Kosovo/ $\mathrm{a}^{31}$. "Planned starvation ${ }^{32}$ was chosen as the mean to deal and resolve the questions that were bothering Serbia since the beginning of the 1990s. Cvijeto Job explains the philosophy behind those policies as such : "Why should we [the Serbs] be a minority in our State, when you [the others] can be a minority in our State ? ". These considerations lived up the policies of " planned starvation " in Kosovo/a that in long term would create a situation of " no minorities at all in my ethnically homogenous State $" 33$. These policies were favoured by the fact that Kosovo/a problematic was considered as an internal issue of Serbia. An issue that both Serb governing authorities and the opposition in a united front did not want to internationalize ${ }^{34}$.

However, the strife between Kosovo/a Albanians and Serbia continued through peaceful means. The only way out of the " planned starvation " situation was the building of a parallel life in Kosovo/a that would give to the Albanians the possibility to survive within Serbia. A shadow State within the State of Serbia was built with its parliament, government and its own financial, educational and health care system. The money for the shadow State was generated by a three percent tax on the monthly incomes of the numerous Kosovo/a Albanian work emigrants in the West 35 .

The authorities of Belgrade tolerated most of the parallel structures created by the Kosovo/a Albanians. No tax-collection and no recruitments for the army was demanded from the Albanians in Kosovo/a. In Troebst terms " the far-reaching separation of Serbian and Albanian societies and "States" contributed to the low degree of political friction $»^{36}$. However, it is worth mentio-

\footnotetext{
${ }^{31}$ Tscherne-Lempiäinen (Paula), From Autonomy to Colonization : Human Rights in Kosovo 1989-1993, Vienna : IHF, November 1993 ; Nizich (Ivana), Yugoslavia : Human Rights Abuses in Kosovo 1990-1992, New York : Human Rights Watch, 1992.
}

${ }^{32}$ Kohl (Ch. Von), Libal (W.), Kosovo : Gordischer des Balkan, Wien/Zürich : Europaverlag, 1992. The " planed starvation " policies in Kosovo/a included expelling Albanians from all-important administrative jobs. Successively, Albanians were removed from the social and education sector and even from employment in other sectors of the economy. At least 100000 Albanians were fired from their jobs to be replaced by Serbs, Montenegrins or pro-Serbian Albanians. At the same time, all Albanian political organizations as well as all cultural and sports associations were forbidden. Most of the Albanian print houses and other media in Albanian language closed down (ibid. ; Schmidt (F.), " Kosovo : The Time Bomb That Has not Gone Off ", RFE/RL Research Report, 2 (39), 01/10/93 ; Troebst (Stefan), art.cit.). With the increasing control of the Serbia over the militia, Albanian contingents were withdrawn from it. In May 1990, in sign of protest all Albanian representatives withdrew from Kosovo/a's government (Troebst (Stefan), art.cit.).

33 Job (Cvijeto), « Yugoslavia's Ethnic Furies n, Foreign Policy, (92), Fall 1993, pp. 52-53.

34 Clewing (Konrad), " Die Radikale Kosovopolitik der Politischen Opposition in Serbia : Noch ein Grund fur Eine Internationalisierung des Serbisch-Albanischen Dialogues n, Sudosteuropa, 44, 1995.

35 Kostovicova (Denisa), " Parallel Worlds : Response of Kosovo Albanians to Loss Autonomy in Serbia, 1986-1996 n, Keele European Research Centre research Papers : Southeast Europe Series, 2, 1997.

36 Troebst (Stefan), art.cit., p. 8. 
ning that both Serb alienating actions introduced in the region and the way the West treated the Kosovo/a problem caused irreparable damages in SerbAlbanian peaceful coexistence. The attitude of neglect provoked an escalation of the demands of the Albanians that rise their demands from a peaceful solution of the situation of repression to the demand for equal entity status within the framework of Yugoslav Federation and later to independence.

The peaceful resistance movement of the leadership of Kosovo/a aiming at gathering international community attention was the response of the Kosovo/a Albanians leaderships to the decisions of the Conference. In their silent contention both Kosovo/a Albanians and Serbs did not work for common solutions. Each party tried to shape its profile and determine the boundaries of contest. In this framework only war was missing from the scene. However, " for several years the rather low degree of frictions and apparent stability of the Serbian-Albanian dualism in Kosovo stunned outside observers and analysts $" 37$. This attitude anticipates the risk of escalating confrontations in the future since parties felt obscurely obstructed for not living up to their own expectation.

\section{DAYTON AGREEMENT AND THE KOSOVO/A CONFLICT [1995-1998]}

Dayton Agreement is another important moment in the Yugoslav dissolution process and Kosovo/a case ${ }^{38}$. The attitude of neglect towards the case of Kosovo/a characterised Dayton Agreement. The main reasons for leaving the Albanians of Kosovo/a out of the deal with Milošević, in Caplan terms are three. First, international community felt that there was simply to much to negotiate with Milošević, and there was already an obstacle to bargain on the cooperation with the Hague tribunal and handing over of the war criminals indicted for it. Second, nobody wanted to alienate Milošević as a peacemaker since he had forced the Bosnian Serbs to accept the compromise, and his cooperation was needed for the implementation of the Dayton Agreement. Third, there was not a war in Kosovo/a, so there was not any urgent need to deal with the question 39 .

Consequently, Kosovo/a leadership was not invited to the negotiating table. The issue of Kosovo/a was mentioned only once in the text of the Dayton

37 Ibid.

${ }^{38}$ Dayton Peace agreement was reached on 21 November 1995 at the Wright-Patterson Air Base in Dayton, Ohio. The Agreement text was signed in Paris on 14 December 1995.

39 Caplan (Richard), "International Diplomacy and the Crisis in Kosovo ", International Affairs, 4 (74), October 1998, pp. 745-761. 
agreement and cited in connection with the preconditions for lifting the " outer wall of sanctions " from Yugoslavia. The " outer wall of sanctions " as a concept was made clear by a Statement issued by the US Department of State, on 23 November 1995 (two days after the agreement was reached). The " outer wall of sanctions " conditioned the full diplomatic recognition of Yugoslavia Federation (Serbia and Montenegro) and its full membership in different international institutions and organisation with Serbia's behaviour towards " Kosovo and cooperation with War Crime Tribunal " and other substantial issues such as the return of refugees and the distribution of the assets of the dissolved Federation $4^{\circ}$. However, trade sanctions against FRY (Serbia and Montenegro) were suspended with the Resolution 1022 of the UN Security Council (20 November 1995) to be completely lifted by the resolution 1047 of the UN Security Council (1 October 1996).

Although, in the moment Dayton agreement was signed there was no war in Kosovo/a, the dispositions of the document signed with Milošević created negative effect with respect to the Kosovo/a case. Implicit solutions offered by Dayton for Serbs and Kosovo/a Albanians made in Troebst terms " the volatility of this unique model of hostile coexistence more than obvious $"^{41}$. Milošević was not blamed for his harsh policy with serious implications for the record of human rights in Kosovo/a. On the contrary, he was prised as a peacemaker and implementer of the Dayton agreement. This situation created a sense of relaxation on the side of Serbia's leadership. The solution of Dayton made clear as British Ambassador to Belgrade Yvor Roberts states that : "Kosovo/a is a question of inside politics of [remaining] Yugoslavia, since it is part of it. The international community keeps repeating that it will not support any secession of Kosovo from Yugoslavia $" 4^{2}$. The political leadership of Serbia including the opposition favoured the preservation of the status quo in terms of Kosovo/a question. The preservation of the status quo favoured the preservation and strengthening of a unitary strong unitary Serb republic as a constitutive unit of Yugoslav Federation. Vuk Drašković43 one of the distinguished representatives of the opposition openly opposed the idea of Kosovo/a becoming a separate federal unit within Yugoslavia. The program of Serbian Radical Party defended the idea that the solution of the Kosovo/a case was a

40 "Statement of US State Department on "Outer Wall of Sanctions" ", USIA Wireless Life, 23/11/95, cited by Hasani (Enver), op.cit., p. 242.

$4^{41}$ Troebst (Stefan), art.cit., p. 8.

$4^{2}$ Naša Borba, 27-28/04/96, as cited by " Kosovo after Dayton Agreement ", Balkan Peace Team, April-May 1996, at http://www.peacebrigades.org/bpt/bptg6-o6.html.

43 President of the Serbian Renewal Party. 
strong unitary republic 44 . The government of Serbia attempted to preserve the power thorough the country by further centralisation of power. The process has started with the removal of the status of autonomy of Kosovo/a and Vojvodina and continued by " pursuing a military solution for the Kosovo problem " 45 . This solution was tacitly encouraged by post-Dayton handling of the Bosnia issue that conveyed the reluctance of international community to do anything that could jeopardize Milošević cooperation in the implementation of the Dayton Agreement.

On the other hand, the international community required the improvement of human rights record in Kosovo/a. The improvement should be at a level that would provide the Albanians with better control of their destiny and the end of the repression atmosphere. In other terms, this meant the recognition of the internal self-determination right to the Albanians in Kosovo/a, which encouraged their hopes for a solution on favour of their expectations for self-rule. After Dayton agreement, Rugova continued with his peaceful negotiating policies. With the intermediation of the Rome-based Catholic religious order Sant'Egidio, some progress in developing an agenda for educational reform was made. The effort concluded with the signing in 1 September 1996 of an agreement between Milošević and Rugova, on the Albanian-language educating system in Kosovo/a, which was never implemented ${ }^{46}$. A small gesture was made on the side of Serbia who removed the exit visa for Kosovo/a Albanians for Albania proper. So, Kosovo/a Albanians could come freely in Albania. Furthermore, some informal talks started between Serb opposition and Kosovo/a Albanian leadership during March and April 1996 in New York and Ulqin [Ulcinj] 47.

However, the signing of the agreement on the Albanian-language educating system was not implemented and nationalistic raids on the side of Serbs make reappearance in Kosovo/a. The record of human rights did not recognize any improvement in the contrary it deteriorated. In the special report of Balkan Peace Team of April/May 1996, Kosovo after Dayton Agreement, human right violation is assessed thoroughly ${ }^{48}$. The human right violation on the side of Serbian authorities against Kosovo/a Albanians after Dayton

\footnotetext{
44 " Kosovo after Dayton Agreement " (art.cit.), p. 6

45 Thies (Wallace J.), art.cit., p. 248.

${ }^{46}$ Nation (Craig), « US policy and the Kosovo Crisis ", International Spectator, October-December 1998.

47 Kosova International Center, 1997, pp.1-2.

$4^{8}$ The Council for the Defense of Human Rights and Freedoms of Prishtina reported that only in the month of March 1986, 839 Albanians were maltreated or tortured by the Serbian police. This number was estimated to be 250 cases more than in the month of February 1996. During the month of April 711 Albanians were maltreated. Only, in the community of Stimlije, 122 persons were maltreated, 116 families were searched, 129 persons were called in for informative talks in the police station.
} 
agreement was reported in the 52nd session of the UN Commission for human rights 49 . "Yet, Rugova had no success in reversing Belgrade's apartheid policies in Kosovo itself. $n^{50}$

In this considerations Dayton Agreement marked a turning point in Kosovo/a Albanian - Serb relations. Facing these developments in the Albanian side voices for radicalisation of the resistance started to gain ground. The Kosova Liberation Army (KLA) or otherwise UÇK (Ushtria Çlirimtare e Kosoves) in Albanian started its operations against the Serbian police and army officers claiming the responsibility for attacks on Serbs during 1995 and $1996^{51}$. The activity was more evident in 1997 and later one during 1998 it was extended almost through the whole Kosovo/a region. These activities were backed up by a group of intellectuals that declared themselves against Rugova's Gandhi policies and were declared in favour of " active civil resistance " against Serbian repression ${ }^{52}$.

Meanwhile, Serb authorities on February 1998 launched a series of largescale operations against the Albanian population and the KLA53. To back up

49 More on the issue of human rights violation in Kosovo/a could be found on : Human Rights Watch Reports on Kosovo :

- Persecution Persists : Human Rights Violations in Kosovo, December 1996 ;

- Human Rights Abuses of Non-Serbs in Kosovo, Sandzak and Vojvodina, October 1994 ;

- Open Wounds : Human Rights Abuses in Kosovo, March 1994 ;

- Abuses Continue in the Former Yugoslavia : Serbia, Montenegro and Bosnia-Herzegovina, July 1993 ;

- Human Rights Abuses in Kosovo, October 1992 ;

- Human Rights in a Dissolving Yugoslavia, January 1991.

50 Troebst (Stefan), art.cit., p. 7.

${ }^{51}$ In April 1996, KLA made his first move with actions in four different places : Peć, Stimlje, Dečan and the Kosovska-Mitrivica-Peć road where 5 Serbs were killed. The action was explained with a communication forwarded to Albanian section of BBC UK service. The militant group declared that " such actions will be a warring to the world for the support given to the Serbian aggression while ignoring the will of the occupied people of Kosovo/a (...). The armed struggle of the Kosova people is not terrorism, inter-ethnic or inter-religion conflict, but rather a war for the liberation of Kosova " (22 April 1996), as cited in " Kosovo after Dayton Agreement " (art.cit.).

Cf. Randal (Jonathan), "Belgrade Feels Tremors From New Violence in Serbia's Ethnic Enclaves ", Washington Post, 30/01/97 ; Abramowitz (Morton), "Ominous Rumblings from the Balkans ", Washington Post, 16/02/98.

52 Qosja (Rexhep), La Question Albanaise, Paris : Fayard, 1995 ; Surroi (Veron), " Mehrheit ond Minderheit in Kosove : Albaner contra Serben ", Internationale Politik, 52 (10), 1997.

53 In Troebst review of the situation " the number of regular police, riot police, and special anti-terror units of the Ministry of Interior of the Republic of Serbia as well the regular forces of the Federal Army of Yugoslavia, volunteers brigades, paramilitary formations, and armed Serbian civilians in Kosovo can only be estimated " (Troebst (Stefan), art.cit., p. 15) by looking at the information offered by both side. An Albanian source, Koha Ditore (01/03/98), reported that " Kosova has 13 ooo Serb police forces - 25000 reinforcement units can be transferred from central Serbia within 72 hours ". A Serbian source, Naća Borba (23/02/98) did report that " in Kosovo, there are permanently between $30000-40000$ policemen " (as cited in Troebst (Stefan), art.cit., p. 15 n. 65). See also Smith (Jeffrey), " Yugoslavia Will Pay a Price, Albright Warns n, Washington Post, 08/03/98, and " Arkan, Perhaps Sighted, Surely Wanted ", Economist, $31 / 01 / 98$. 
Serb authorities large-scale operations the paramilitary forces of Serbian Volunteer Guard-known better as the "Tigers " of Arkan in January 1998 returned in Kosovo/a to intimidate the civil population 54 . The operations " left some 400 dead and forced tens of thousands to flee their homes and villages $" 55$. The escalation of confrontations between Serb military and para-military forces with the KLA was exuberated in summer 1998 and a new escalation started in 1998/1999 winter triggering NATO intervention in March 1999.

In Troebst's terms : " Dayton - triggered changes in the tectonics of "parallel" power in Kosovo [that] led the three main political currents, the pacifists, the activists and the militants, to intensify their respective endeavours $" 56$. These changes stimulated important developments in the political conceptualisation of the Kosovo/a case. It was just after Dayton that " the province's Albanian majority raised its sights from republic status within what remained of Yugoslavia to independence $" 57$. The radicalisation of the position and mutually excluding solution that both Serbs and Albanians consolidated after Dayton made clear that parties have to fight war for defending their choices.

\section{PREVENTIVE DIPLOMACY AND RAMBOUILLET TALKS [1998-1999]}

Preventive diplomacy was the next stage that filled the record of international community involvement in the Kosovo/a case. In this phase the involvement was specific to the case since it dealt explicitly with the parties in the conflict. The previous involvements of international community (Conference on Yugoslavia, Dayton Agreement and other diplomatic efforts such as Sant'Egidio catholic order) by prescription or recommendations have accorded differentiated treatments to the Kosovar Albanian in relation to the other minorities of the former Yugoslavia. In Caplan's terms :

Whether warranted or not, this approach helped ensure that Kosovo would fail to become a major international concern, thus allowing the conflict to smoulder for years. The explosion of pent-up frustration we are witnessing today in Kosovo is only one consequence of these actions. Another is that the scope for moderate so-

\footnotetext{
54 " It's War ", Economist, 07/05/98.

55 Caplan (Richard), art.cit. ; Soloway (Colin), "Serbia Attacks Ethnic Albanians ", Washington Post, 06/03/98 ; Smith (Jeffrey), "Eerie Quiet Follows Assaults in Kosovo ", Washington Post, og/03/98 ; Daalder (Ivo), O'Hanlon (Michael E.), Winning Ugly: NATO's War to Save Kosovo, Washington : Brookings Institute, 2000, pp. 27-28.

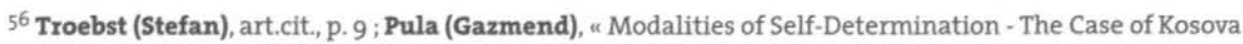
as a Structural Issue for Lasting Stability in the Balkans ", Sudosteuropa, 45, 1996, pp. 380-410 ; " The Albanian National Question : The Post-Dayton Pay-Off n, War Report, (41), 1996.
}

57 Thies (Wallace J.), art.cit., p. 247. 
lutions has narrowed. Genuine democratisation of Serbia may enlarge the political space required to restore credibility to compromise solutions but the prospects for such a development in the short term are weak ${ }^{58}$.

The arrangements offered by international community as solutions to the Yugoslav dissolution process did have implicit implications in shaping the characteristics of the Kosovo/a case and at the same time could be perceived as the fuse for exuberating the controversies between the conflicting parties. From 1998 onwards, the situation in Kosovo/a escalated towards violent confrontation with serious casualties (as evidenced above). Several international attempts were carried out to stop the conflict. The last effort before the war erupted was brought about during the Rambouillet peace conference talks in February and March 1999.

In February 1998, the US initiative to settle the situation witnessed Robert Gelbart, the US Special Envoy for the implementation of the Dayton Agreement to come to Belgrade and talk with Milošević. Two options were offered to Milošević either be constructive in finding solutions to the Kosovo/a problem, or be punished by further sanctions and isolation if the violence escalated in the region 59 . On the other hand by defining the KLA as " without any questions a terrorist group " 60 and publicly prizing Milošević, implicitly Gelbart furnished legitimacy to Milošević policies, since they appeared to be triggered by unlawful actions of the KLA. Afterward, Gelbarts declarations were in compliance with the justifications of Belgrade regime that blamed all what was happening in Kosovo/a to the KLA insurgent activities.

In an effort to build cause effect relationship in the declaration it become simple to understand that the causes of the conflict were assigned to the terrorist actions of the KLA. This assessment of the case triggered violent reactions on the side of Serbia that abet from international law deliberations took the necessary measures to settle an internal insurgent activity. This argument felt on a perfect match with the justifications given by the Serbian Government that later on were formalised in a document entitled Terrorism in Kosovo and Metohija ${ }^{61}$. In the document is stated "Albanian terrorism, oriented toward driving out the Serbian and other non-Albanian populations from Kosovo and Metohija, has lasted for centuries [aiming] to create ethnically pure territories in Kosovo and Metohija and to promote the secession of this region ". The cards of secessions and terrorism towards which international community is no tole-

$5^{8}$ Caplan (Richard), art.cit. p. 745.

59 Daalder (Ivo), O'Hanlon (Michael E.), op.cit., p. 27.

60 Gelbart (Robert), " Press Conference ", Zagreb, October 23, 1998.

${ }^{61}$ Terrorism in Kosovo and Metohia and Albania - The White Book, Belgrade : Federal Ministry of Foreign Affairs, 1998. At $h$ ttp://www.serbia-info.com/news/kosovo/terrorism/terrorism.html. 
rant were used as a cover by Milošević to pursue the campaign of violence in Kosovo/a. The Serb authorities found in the KLA a legitimate pretext for brutally unlawful measures. This pretext was used by Miloševic to provoke widespread Albanian uprising and then to go on with the war and justify the ethnic cleansing and genocide at worrying levels ${ }^{62}$. In the beginning of February, Milošević could get away in restoring credibility about the rightness of his policies.

The parties in terrain reacted on these circumstances. Series of attacks were launched against Albanian villages with casualties that included children and old peoples. The policy of the "burn land " was used to compel Albanians to flee their homes and villages ${ }^{63}$. The massacre in Drenica, in the beginning of March 1998, where some 80 Albanians were killed, among them 25 women and children, foreordained for the seven months of open war. The brutality of Serbia's leadership actions in Kosovo/a made clear to international community as Craig Nation states that : "Serbian repression was now interpreted not merely as an exaggerated reaction to a domestic insurgency, but as a campaign launched with genocidal intentions at the Kosovar Albanian population as a whole ${ }^{64}$.

Following these developments, on 9 March 1998, Contact Group for the Balkans (the US, Britain, France, Germany, Italy and Russia) convened. The Contact Group condemned the actions of violence and threaten to establish an arm embargo and other stronger sanctions on Belgrade, if Serbs did not halt their attacks in Kosovo/a, withdraw paramilitary forces and allow outside investigators to monitor the situation ${ }^{65}$.

On 31 March 1998, the UN Security council formalized through the Resolution 1160 serious warnings, for both parties Serb Government and the Kosovo/a Albanian leadership. The Resolution 1160 condemned " terrorism by the Kosovo Liberation Army or any other group or individual and all external support for terrorist activity in Kosovo, including finance, arms and training " so for " the use of excessive force by Serbian police forces against civilians and peaceful demonstrators in Kosovo ". The Resolutions demanded from parties " to urgently enter without preconditions into a meaningful dialogue on the political status issues " with " the participation of an outside representative or representatives " otherwise " extra measures will be taken " 66 .

${ }^{62}$ Maliqi (Shkëlzen), " Beyond Drenica, Crisis of Kosova ", Transitions, 5 (4), April 1998.

63 Soloway (Colin), art.cit ; Smith (Jeffrey), "Eerie Quiet Follows Assaults in Kosovo " (art.cit.) ; Daalder (Ivo), O'Hanlon (Michael E.), op.cit. ; Soloway (Colin), Stephen (Ch.), " Kosovo under Second Day of heavy Serb Assault ", Washington Post, 07/03/98.

64 Nation (Craig), art.cit., p. 4.

65 Swadson (A.), " Russia Agree on Sanctions for Belgrade ", Washington Post, 10/03/98 ; Drozdiak (W.), "West Vows New Sanctions on Yugoslavia ", Washington Post, 26/03/98.

66 " UN Security Council Resolution 1160 n, 31 March 1998. 
However, behind the threats only sanctions were intended. The re-establishment of sanctions in the case of Bosnia showed infectivity in changing Serbia's policies or weakening Milošević at least until the moment the military actions took precedence. In Thies terms " Bosnia precedent also suggested that sanctions would not work quickly enough to prevent the Serbs from brutalizing Albanian civilians in Kosovo " ${ }^{67}$. In fact the sanctions proved to be ineffective, since there was no serious commitment to the use of force as alternative solution, in the case of sanctions policy inefficiency. By April 1998, the situation started to deteriorate again. The Economist would define as such the situation : "As the death toll amounts and Kosovo's Albanians head over the mountains to Albania proper for more guns, it is becoming harder to deny the obvious : another Balkan war, albeit so far at a low level, has begun "68.

The situation proved to enter a deadlock status since in Thies terms : Every public warning or threats issued by a representative of the US or another NATO country between March and June 1998 was followed in short order by renewed Serb military actions, which was then met by more empty threats. By the summer of 1998 , the Serbs had proven-repeatedly-that threats by the US and its NATO allies could be safely ignored 69 .

Serbs did customize with threats in words that were undercut by empty warnings for actions. Furthermore, international community with its policies of insistence on the preservation of Serbia's frontiers nourished Serbia phobia that Kosovo/a was an internal issue of Serbia and explicitly was in its rights to resolve it the way it considered as appropriate to its interest ${ }^{70}$. This believes was put across even upon the unpublished agreement between Milošević and Richard Holbrook, which was considered in " harmony with the constitution of the Republic of Serbia and Yugoslavia " $^{71}$.

In September, another Resolution of the UN Security Council, $1199^{72}$ asked for the immediate cease-fire and return of the refugees. The Resolution 1199 was more extreme in the formulation of threats compared to resolution 1160. The Resolution threatened that " extra measures and extra actions will be considering " underlining as such the use if necessary of the military actions still the statement was not explicit on this direction. However, both

${ }^{67}$ Thies (Wallace J.), art.cit., p. 249.

68 "It's War " (art.cit.).

${ }^{69}$ Thies (Wallace J.), art.cit., p. 252.

${ }^{70}$ Malcolm (Noel), Kosovo : A Short History, London : Macmillan Press, 1998 ; Zimmerman (Warren), « The Demons of Kosovo ", The National Interests, 52, Spring 1998.

${ }^{71}$ Milošević (Slobodan), "Interview to the Washington Post ", Serbia in the World, Special Supplement, Belgrade : The Ministry of Information of the Republic of Serbia, November 1998.

72 " UN Security Council Resolution 1199 ", 23 September 1998. 
Resolutions co-sponsored by Russia (China abstained) imposed embargo onYugoslavia and called for cease-fire and finding of a solution in compliance with the preservation of peace and stability in the region 73 .

Following on the decisions of the Resolution 1199, negotiations started between Milošević and Richard Holbrook the US special envoy. Milošević accepted the agreement on cease-fire, return of the refugees and achievement of an agreement on the core elements for a political settlement in Kosovo. The agreement was going to be observed by the OSCE. The agreement was refused by the KLA that was not called to be part of the negotiations ${ }^{74}$. Soon after, the agreement declined to achieve anything and on the ground the fighting reassumed. Serbs restarted the fighting under the Operation Horseshoe that in essence aimed the shift of the ethnic balance in Kosovo/a75. In Daadler and O'Hanlon : " the attacks would involve a broad swath of territory in the shape of a horseshoe, moving from the northeast down to the west and back to the southeast of Kosovo along the Albanian and Macedonian borders. It also apparently entailed empting the cities of Prizren, Pec and Prishtina of their largely Albanian population $»^{76}$.

The January of 1999 brought another set of diplomatic efforts combined with threats for the usage of force. Contact Group endorsed a plan on 22 January for imposing a political solution, including using force if either one ore both parties the Serbs or the KLA refused to accept the deal. NATO pledged to back up the decisions of the Contact Group in using force in case the agreement would be turned down.

On the 6 of February, the Rambouillet negotiations between Serb's leadership and Albanian's leadership started including the KLA that before was labelled as a terrorist organization 77 . This change on the attitude of international community towards the KLA was based on two considerations. First, the

73 In international community vocabulary peace and stability at international or regional level imply first of all the preservation of the internationally recognized borders. The Helsinki Acts of 1975 instituted this precondition.

74 The issue of negotiations between Serbs and Albanian is complicated from the conditionality that both parties have made public. Serbia's leadership fearing that international mediation would be in its disfavour organized a referendum asking the people about the presence of foreign intermediary(ies) on the Kosovo/a negotiations. The majority of Serbs refused the presence of foreign mediators on the Kosovo/a negotiations. On the other hand, Kosovo/a leadership due to lack of confidence to Serb's leadership refused to enter in negotiations without foreign mediators. Furthermore, the KLA threaten that any agreement with the Serbs without the guarantee of the foreign mediators was going to be considered as betrayal and punished accordingly (Isakovic (Zlatko), art.cit).

75 Ignatieff, (Michael), Virtual War. Kosovo and Beyond, New York : Henry Holt \& Company, 2000 ; Daalder (Ivo), O'Hanlon (Michael E.), op.cit. ; Bellamy (Alex J.), Kosovo and International Society, New York : Palgrave Macmillan, 2002.

${ }^{76}$ Daalder (Ivo), O’Hanlon (Michael E.), op.cit., p. 59.

77 Judah (Tim), Kosovo: War and Revenge, Yale : Yale University Press, 2000. 
brutality and continuity of Yugoslavia's attacks on ethnic Albanians and the inability of Albanian leadership to counter it has marginalized Ibrahim Rugova, the moderate leader who was elected president of the self-declared Republic of Kosovo and who advocated nonviolent resistance. Many of his former supporters did join the KLA, which stepped into the vacuum left by Rugova. By the end of 1998, the KLA was a well-organized movement, with a military general staff and a civilian political directorate. The directorate was headed by Hashim Thaci, who attended the Rambouillet peace talks ${ }^{7}$. Thus, KLA become the most significant force resisting Yugoslav aggression within Kosovo and enjoyed large popular support and legitimacy among the Albanians79. Second, getting the KLA as a negotiating party was going " to drive up the costs of Milošević's repression in Kosovo and give him greater incentives to negotiate a settlement acceptable to NATO ${ }^{80}$. In this circumstance the KLA could not be left out of the Rambouillet political settlement.

The first text of Rambouillet talks, which was presented to the Albanian and Serbian parties had five main points : immediate cessation of the violence ; withdrawal of FRY military, police and paramilitary form Kosovo/a ; the stationing of an international military force led by NATO ; the safe return of the refugees and displaced peoples ; a political solution for an extended autonomy of Kosovo/a. Both parties rejected the deal. The Serbs rejected the presence of foreign troops in their territory (Kosovo/a was considered as a domestic issue of Serbia). Albanians rejected the option of extended autonomy, a status that they did gain with the constitution of 1974. In Kosovo/a Albanians' logic the development of the situation in the ground has whacked out this option. Ten years of repression culminating in brutal actions convinced virtually all Kosovo/a Albanians that they could not remain in the same State with the Serbs. Consequently, the only solution consented by all Kosovo Albanian political spectrum was the option of independence ${ }^{81}$.

The negotiations reassumed on March 15, 1999. The new text of the negotiations offered an extended autonomy that assumed democratic self-government for all domestic issues such as education, health and economy. Kosovo/a was going to have its President and Assembly. Foreign troops and officials were going to guaranty the agreement. The extended autonomy was going to be offered for an interim period of three years. Then, in a three-year period an international conference was going to be convened to decide on the final sta-

${ }^{78}$ Hutchinson Encyclopedia, "Kosovo Liberating Army ", at http://www.tiscali.co.uk/reference/encyclopaedia/hutchinson/moo89392.html.

${ }^{79}$ Anderson (James), Phillips (James A.), "The Kosovo Liberation Army and the Future of Kosovo ", The Heritage Foundation, 13 May 1999 (at : http://www.heritage.org/Research/Europe/BG1280.cfm).

${ }^{80}$ Ibid.

${ }^{81}$ Moore (Patrick), " Albanians With Whom One Can Talk ", RFE/RL Balkan Report, 4 (88), 15/12/o0. 
tus of Kosovo/ $/ \mathrm{a}^{82}$. However, in essence territorial integrity and the sovereignty of Serbia were going to be preserved ${ }^{83}$. The Albanian side signed the deal but the Serbs rejected it. This was considered as the causis belli to yield the military response of NATO soon after the talks did end.

\section{CONCLUSIONS}

The international practice in the case of conflict such as the one of Kosovo/a as it was argued throughout the paper appears to be increasingly controversial. Intra-State conflicts represent anomalies in the traditional normative framework where there is confusion as to the nature of the actors subject of protection and the relevance of domestic structures in the relations between the States and order in international relations. As the case of Kosovo/a demonstrated, the States centric concept of authority and related practices revealed to be detrimental in the sense of scarifying other human values for those of sovereignty and territorial inviolability. Giving a privileged position to the State grant to it a predominant position that exclude others such as trans-national actors, communities and individuals from the same privileges. Furthermore, international society by the policy of non-recognition ${ }^{84}$ denies the recognition to these new actors and turn down their claims to self-determination. The international efforts to preserve this traditional normative framework as a prerequisite for order could give forth war if claims of different ethnic groups for self-determination are faced with repression and deterioration of human rights. Furthermore, this war threatens to become a serious threat to order affecting not only the State in question but the countries of the region as well. The efforts to produce order could produce opposite effect : war and disorder.

In practical terms actors in intra-State conflicts, by subscribing to the nation-State ideal, aim to match their national and ethnic identities with their own sovereign governments in a defined territory. Although this may be considered an ideal solution to the current problematic, there is uncertainty in today's political circles about the framework of political actions deriving from the limitation shaped by the established society of States. In George White

\footnotetext{
82 " Interim Agreement for Peace and Self-Government in Kosovo, March 1999 ", in Veremis (Thanos M.), Traintaphyllon (Dimitros), eds., Kosovo and the Albanian Dimension in Southeastern Europe: The Need for Regional Security and Conflict Prevention, Athens : ELIAMEP, 1999, pp. 261-330.
}

${ }^{83}$ Majstorovic (Steven), "Autonomy of the Sacred : The End Game in Kosovo ", Nationalism and Ethnic Politics, 5, Autumn-Summer 1999, pp. 3-4.

84 Aron (Raymond), Peace and War : A Theory of International Relations, Malabar : R.E. Krieger Pub. Co, 1981. 
words « the recognition of another nation's right to independence may not in principle be the issue ; recognition is withheld to forestall an even more difficult question : Which nation receives which territory as part of an independent declaration ? " 85 . In the present normative framework, the current answer is defined in terms of uti possidetis, a politico-legal principle associated with the rights of sovereignty that manages the territorial claims made by successor States to former multi-national State possessions. The applicability of this principle aimed at countering secessionist arguments based on ethnicity and exclusive identities.

This traditional normative framework reminds us of the medieval Western Europe where the institution of Church was a very strong influence and nothing existed but Christianity as a norm of both coexistence and supreme authority in interrelations. To some extent, the " ideology " of the time, although legitimised by divine prepositions, maintained stability and order. The earth was God's garden, things were the way God had made them, and it was a sin to believe that one could improve upon God's work. This logic implies an understanding of the world, as it was with "States acting as bastions of mutually exclusive identities " and " sovereignty of States as the foundation of societal relations among them " 86 . From a practical perspective this understanding lays a framework of actions and strategies that is misleading since it ignores the consequences of State actions on " other " peoples ${ }^{87}$. The conceptualisation of State society remains exclusivist and perpetuates patterns of alienation, exploitation and discrimination that create sources for conflict ${ }^{88}$, which consequently create premises for the breaking of order.

The external/internal divide is somehow a barrier that prevents the extension of order with justice beyond the State borders and the case of Kosovo/a provided rich evidence on that. May be the time has come to give more space to the ignored voices and show the political courage to absorb all we have been going through during Kosovo/a conflict, to recognise all that has changed and to adapt to all that is about to change again. A new approach is needed to reconcile the extremes and move beyond traditional normative approach in international relations " to a set of ideas which offer a fuller understanding of

\footnotetext{
${ }^{85}$ White (George W.), Nationalism and Territoriality, Constructing Group Identity in Southeastern Europe, Oxford : Rowman and Littlefield Publishers, 2000, p. 2.

${ }^{86}$ Buzan (Barry), art.cit., pp. 337, 339.

${ }^{87}$ Moller (Bjorn), « National, Societal and Human Security-A General Discussion with a Case Study from the Balkans ", COPRI Working Paper, 37, 2000.

${ }^{88}$ Booth (Ken), " Human Wrongs and International Relations ", International Affairs, 71 (1), January 1995 ; Linklater (Andrew), " Neo-Realism in Theory and Practice ", in Booth (Ken), Smith (Steve), eds., International Relations Theories Today, Cambridge : Cambridge University Press, 1995.
} 
the forces shaping "who gets what, when and how" "89. Such approach should cope with the complexity of politics at the global level where global factors are impinging upon : State authority, closing the gap between domestic/foreign ; political identities where local loyalties are faced with the need to share global values. Understanding globalisation of political life requires, as Booth perceives it " a different framework for understanding " $99^{\circ}$. This approach should be " global " and " eclectic ", and " borrowing of insights from a range of perspectives - the world society school, international political economy, comparative politics and critical theory-as well as other disciplines ${ }^{91}$. A holistic approach is needed coping with exclusivist premises while providing pertinent explanations of the events and trends in world political level.

${ }^{89}$ Booth (Ken), "Security in Anarchy : Utopian, Realism in Theory and Practice n, International Affairs, 64 (3), 1991, p. 534.

$9{ }^{\circ}$ Ibid., p. 537.

${ }^{1}$ Ibid. 